\title{
REDESAIN TAMAN KOTA TRUNOJOYO KOTA MALANG MELALUI
} PENDEKATAN LANSKAP KOTA

\section{Redesign of Trunojoyo City Park in Malang City through the Cityscape Approach}

\section{Irawan Setyabudi}

Universitas Tribhuwana Tunggadewi Malang

Email: isetyabudi.st@gmail.com

Viktor Tharigas Sianus Agus

Program Studi Arsitektur Lanskap Universitas Tribhuwana Tunggadewi Malang

Email: viktortharigas69@gmail.com

Diajukan: 1 Agustus 2020

\begin{abstract}
Currently, Malang City has many parks that can attract tourists. Besides being supported by its location in the highlands with a relatively comfortable temperature. Since several years ago, open spaces in the city have been explored into attractive thematic parks according to the problems in that location. One of them is Trunojoyo Park. This park is located in front of Kota Baru Station, precisely on Jalan Trunojoyo near Tugu Square, the center of Malang. The station is the entrance to the city from the passenger side of the train. When passengers leave the station area, they will see Trunojoyo Park. From another point of view, public and private vehicle drivers from Tugu Square's direction or vice versa also pass through the park. The park has a right and a left side. The center of the park's crowd is only on the right side of the park, and the two parks look separate and not together; this is because the facilities are complete. Its current existence has a problem that visually does not reflect the City of Malang, especially from the side of train passengers who come from outside the region. However, from the function aspect, the community has used the park properly, such as recreational and sports functions. Landscape elements need to be developed from previous designs to become a point of interest for visitors. This research aims to redesign Trunojoyo Park to reflect the image of Malang as a historic city and the entrance area of Malang from the railway. The research method used qualitatively with a practical design approach, namely problem identification, analysis-synthesis, concept, design, and development. The output produced is in the form of a design concept and a design drawing such as plans, views, cuts, plans, and details. This research's result is that the evaluation of the previous design will create a more aesthetic and functional design in the future.
\end{abstract}

Keywords: garden design recommendations, identity, Malang City, visitor behavior

Diterima: 29 September 2020

\section{PENDAHULUAN}

Kota Malang memiliki berbagai potensi lanskap alami, buatan, dan budaya masyarakat yang masih asli. Sumberdaya alam dan budaya masyarakat yang khas tersebut perlu dipertahankan dan dilestarikan. Saat ini Kota Malang memiliki banyak taman yang mampu menarik wisatawan. Selain didukung oleh lokasinya yang berada di dataran tinggi dengan suhu yang relatif nyaman. Sejak beberapa tahun lalu, ruang terbuka di kota ini dieksplorasi menjadi taman tematik yang menarik sesuai dengan permasalahan di lokasi tersebut. Salah satunya adalah Taman Trunojoyo.

Taman Trunojoyo terletak di depan Stasiun Kota Baru, tepatnya di Jalan Trunojoyo - dekat Alun-Alun Tugu yang merupakan pusat Kota Malang. Menurut Santoso, et al. (2018), Kota Malang termasuk bagian perencanaan kota kolonial dengan kaidah modern, dengan perencana Ir. Herman Thomas Karsten. Adapun Identitas stasiun kota baru sangat melekat dengan gaya arsitektur nieuwe bouwen. Karakternya ditandai dengan dominasi cat warna putih, gevel bukan segitiga tetapi mendatar, atap mendatar, massa bangunan berbentuk kotak, serta material struktur utama beton dan penutupnya dengan batu bata. Stasiun Kota Baru telah berhasil dikonservasi dengan tidak merubah bentuknya sampai saat ini. Di sisi lain kawasan alun-alun, dikembangkan dengan konsep Garden City yang ditandai dengan adanya kantor pusat pemerintahan dengan pelataran dan pedestrian yang cukup luas. Thomas Karsten berhasil mengubah image pada alun-alun tugu mengikuti kaidah tata ruang alunalun berpakem jawa yang sebelumnya dihilangkan oleh penguasa lokal pada alun-alun kota lama. Sebelumnya, posisi kantor bupati menyisih sebelah utara dan fasad pendopo ke sebelah selatan. Alun-alun tugu memiliki monumen di tengahnya, diresmikan oleh Ir. Soekarno tahun 1950-an dan masih terjaga keindahannya sampai sekarang. Titik pusat tersebut sebagai icon dan tetenger Kota Malang. (Budiyono, et al. 2012)

Posisi stasiun menunjukkan sebagai pintu masuk (entrance) kota dari sisi penumpang kereta. Saat penumpang meninggalkan area stasiun, mereka pasti akan melihat Taman Trunojoyo. Dalam sudut pandang lain, pengemudi kendaraan umum dan pribadi dari arah Alun-Alun Tugu atau sebaliknya, juga melewati taman tersebut. Area taman terbagi atas sisi kanan dan kiri, selaras dengan bentukan fasade stasiun. Pusat keramaian taman hanya berada di sisi kanan taman dan kedua taman terlihat terpisah dan tidak menyatu, hal ini dikarenakan fasilitas yang lebih lengkap. Menurut Putri, et al. (2017), fasilitas ruang publik yang disediakan direvitalisasi dengan tema taman pintar atau education-interactive. Area ruang dibagi atas tujuh wisata utama yaitu perpustakaan, playground, plaza, amphiteather, pujasera, grass area, dan air mancur. Area playground memiliki dominasi aktivitas dibandingkan dengan area lainnya. Eksistensi dan posisi elemen atraktif serta kebutuhan tempat duduk menjadi elemen penarik pengunjung. Namun demikian, menurut pola aktivitas yang terbentuk, perlu pengolahan desain pada area hijau sehingga fungsinya dapat optimal sebagai fungsi rekreasi dan edukasi.

Keberadaannya saat ini memiliki permasalahan yang secara visual kurang mencerminkan identitas Kota Malang sebagai kota bersejarah. Kondisi eksistingnya sebagai berikut, taman ini sudah memiliki tanaman 
peneduh yang sangat baik dan dengan jarak tertentu terdiri atas beringin dan flamboyan, tanaman perdu yang seragam dengan warna ungu, tanaman pembatas pagar dengan penitian. Kekurangan dari aspek softscape adalah beberapa area belum memiliki groundcover berupa rumput sehingga terlihat kurang asri. Elemen hardscape yang dibentuk berupa street furniture dengan unsurnya bangku taman, tempat sampah, titik lampu dengan penempatan cukup baik, namun struktur tenda sebagai point of interest kurang kontekstual dengan karakter Kota Malang. Begitupula dengan pagar besinya, seakan membatasi ruang secara tegas dan kaku. Masalah desain lainnya adalah penataan ruangnya belum terbagi atas zoning sehingga persebaran pengunjung kurang merata, selain itu antara taman sisi kanan dan kiri belum ada penghubung (intersection) dan tampak terpisahkan oleh patung singa, selain itu para pengunjung dari arah stasiun belum terwadahi fasilitas penyeberangan sehingga enggan untuk mengunjunginya. Di sisi lain, dari aspek fungsi, taman sudah digunakan dengan baik oleh masyarakat untuk rekreasi, bermain dan olahraga ringan.

Studi ini bertujuan untuk meredesain Taman Trunojoyo Kota Malang, agar dapat dikembangkan sebagai taman yang kontekstual dengan karakter Kota Malang sebagai kota bersejarah. Output yang dihasilkan adalah berupa gambar rencana. Adapun tujuan tulisan yaitu mengidentifikasi dan menganalisis potensi dan kendala di Taman Kota Trunojoyo Kota Malang, kemudian menentukan konsep dasar, desain dan pengembangan yang menyesuaikan dengan unsur-unsur dan prinsipprinsip desain dan rekomendasi desain Taman Kota Trunojoyo Malang agar terintegrasi dengan alam melalui pendekatan lanskap kota.

Sebelum membahas lebih jauh, perlu diketahui referensi yang berkaitan tentang taman kota dan pendekatan analisisnya. Taman Trunojoyo merupakan salah satu bentuk dari ruang terbuka hijau. Menurut Peraturan Menteri No. 05 tahun 2008, definisi ruang terbuka hijau (RTH) adalah daerah yang berwujud bisa memanjang atau berbentuk jalur, bisa satuan atau mengelompok dengan fungsi yang bersifat terbuka, tempat tanaman hidup, baik yang sengaja ditanam ataupun secara alami. Taman Trunojoyo dapat diklasifikasikan sebagai taman kota namun dengan ukuran yang lebih kecil. Menurut peraturan tersebut definisi taman kota adalah RTH yang dapat melayani minimal 480.000 penduduk, standar minimal $0.3 \mathrm{~m}^{2}$ per penduduk kota dan luas $144.000 \mathrm{~m}^{2}$. Fungsi taman berupa rekreasi dan olahraga dengan prosentase $80-90 \%$ dominasi RTH. Berdasarkan hasil identifikasi permasalahan, Taman Trunojoyo dirancang dengan pendekatan lanskap kota. Maksud pendekatan tersebut adalah sebagai berikut, menurut Permana dan Fatimah (2017), urban landscape design atau pendekatan lanskap kota merupakan suatu rancangan dengan pemanfaatan sumber daya terkini dan dialihbentukkan menjadi karya yang dicintai semua orang karena sense of belonging dan keterpenuhinya kebutuhan manusia. Suatu rancangan agar bisa dimiliki oleh setiap orang maka harus kontekstual dengan style perkotaan, dalam hal ini kesan kota bersejarah. Amin (2012) menjelaskan bahwa pendekatan lanskap perkotaan terdapat prinsip untuk menciptakan kombinasi visual tanaman yang menarik, memenuhi kriteria keselamatan dan kesehatan, dan meningkatkan iklim mikro pada lingkungan lanskap. Begitupula Utomo (2012), menjelaskan lanskap kota dibentuk dari ruang terbuka dan ruang terbuka hijau dalam perkotaan yang tidak terpisah dari bangunan dan struktur ruang di sekitar, dengan fokus berupa sosial, estetika dan lingkungan. Menurut Syafiq (2017), pendekatan tersebut berarti ruang terbuka perkotaan untuk meningkatkan kualitas hidup pengunjung dan masyarakat sekitar. Pendekatan tersebut untuk melestarikan dan menghormati nilai ekologi dan budaya. Adapun kriterianya (a) adaptasi: lanskap kota selalu bersifat dinamis sehingga produk desain tidak pernah selesai, sehingga fleksibilitas tersebut dicapai dengan pemilihan material yang sesuai, (b) keterbacaan: pemahaman tentang tempat dan memberikan kesanmakna pada pengguna, dengan mempertimbangkan kesejarahan, material, keamanan, dan atraktif, (c) keterlibatan masyrakat dalam proses desain, dengan pertukaran informasi sehingga masyarakat merasa memiliki.

\section{METODE PENELITIAN}

\section{Waktu dan Lokasi}

Penelitian ini dilakukan di Taman Trunojoyo tepatnya berlokasi pada Jalan Trunojoyo, Klojen, Kota Malang, (Gambar 1). Lingkup wilayah penelitian adalah seluas area taman di sisi kanan dan kiri dari arah stasiun. Penelitian ini dilakukan selama 6 (enam) bulan di lapang mulai bulan Maret sampai dengan Oktober 2019.

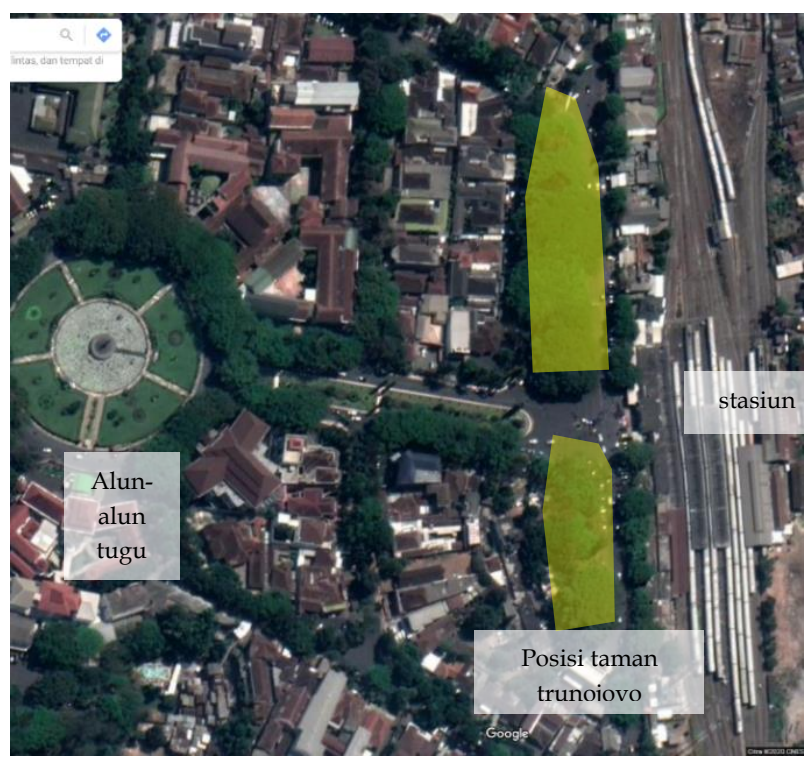

Gambar 1.Peta Lokasi Penelitian Sumber : google maps (2020)

\section{Metode Pengumpulan Data}

Data terdiri atas data primer dan data sekunder. Data primer berupa survey lapangan, foto-foto dan wawancara dengan pengunjung taman. Data sekunder dari buku referensi dan jurnal.

\section{Metode Analisis}

Metode penelitian dilakukan secara kualitatif dengan penjabaran atau deskriptif. Penelitian deskriptif-kualitatif (QD) merupakan penelitian untuk mengkaji peristiwa atau aktivitas sosial secara alami dengan aksentuasi pada cara penafsiran, pemahaman pengalaman, dalam 
menjabarkan realitas sosial sehingga peneliti mampu memecahkan permasalahan sendiri. (Creswell dan Poth, 2016). Penelitian ini juga memiliki alur induktif dengan penjelasan sederhana (Yuliani, 2018). Selaras dengan Gunawan (2013), metode ini lebih pada sifat fenomenologis yang menghasilkan penghayatan peneliti. Analisis data dilakukan sebelum-selama-dan sesudah di lapangan. Sebelum terjun lapangan diperlukan triangulasi untuk menguji validitas saat interpretasi untuk menarik kesimpulan. Kekuatan metode ini berdasarkan fleksibilitas gaya peneliti dalam menjabarkan, sedangkan kelemahannya dari seberapa detail peneliti dalam menangkap momen dan menjelaskannya.

Metode analisis secara arsitektural diilhami dari pemikiran Gold (1980), Hakim \& Utomo (2012) dan diperkuat oleh Setyabudi (2016) dengan pendekatan lanskap kota. Tahapan teknisnya antara lain: inventarisasi, analisis-sintesis (tapak dan aktivitas), konsep, perancangan dan pengembangan rancangan. Adapun secara detail penjelasannya sebagai berikut.

\section{a. Tahap Pendataan atau Inventarisasi}

Pada tahap ini ada pendataan eksisting taman seperti ukuran taman, peta lokasi dari google maps atau peta dari kantor pemerintahan, dokumentasi foto dan penalaran masalah yang ada di lapangan. Berbekal gambar rancangan yang sudah ada dapat digali potensi permasalahan rancangan sebelumnya. Tahap ini juga penggalian informasi dari pengguna terhadap taman. Inventarisasi ini juga mewakili kajian pendahuluan yang mana lahan bukan berupa lahan kosong sehingga diperlukan redesain. Menurut Helmi (2008), redesain merupakan perancangan ulang pada sistem, struktur, fungsi, atau bagian lain untuk mendapatkan manfaat yang lebih baik.

\section{b. Tahap Analisis}

Analisis yang dilakukan adalah analisis tapak dan pengguna. Analisis tapak terdiri atas kondisi alami, hidrologi, klimatologi, topografi dan potensi lain pada tapak. Di sisi lain, analisis pengguna terdiri atas analisis aktivitas, kebutuhan ruang dan fungsi.

\section{c. Tahap Skematik}

Tahap ini berupa sintesis dari tahap sebelumnya dan dilanjutkan dengan konsep ataupun studi olahan 3 dimensi. Konsep programatik mengacu pada gagasangagasan yang dituju terutama sebagai pemecahan fungsional dan operasional. Konsep tersebut adalah gagasan umum dan mengacu pada tapak. Di samping itu, perlu dibedakan dengan konsep desain. Konsep desain mengacu pada gagasan programatik yang disajikan bukan uraian atau gambaran konsep teoritis melainkan konsep pemecahan masalah ke dalam tapak.

\section{d. Tahap Perancangan atau Desain}

Tahap ini merupakan tahapan rancangan, yaitu ulasan keputusan pemecahan masalah dalam bentuk rancangan walaupun masih bersifat sementara. Dengan kata lain yaitu pengaplikasian konsep program ke dalam tapak melalui pertimbangan arsitektural, yaitu tema, komponen pembentuk ruang, bentuk/gaya, fungsi ruang, kesan ruang, nilai ruang, komposisi, skala, warna, bahan material (alami/buatan), sistem konstruksi, estetika, tekstur, dan lainnya. Output minimal yang dihasilkan pada tahap ini adalah gambar site plan dan gambar lain yang dianggap penting seperti rencana vegetasi.

\section{e. Tahap Pengembangan Rancangan atau Desain}

Tahapan ini merupakan tahapan keputusan atau tahap final dari pemecahan masalah desain yang nantinya menjadi dasar bagi rancangan detail selanjutnya. Wujudnya berupa kelengkapan gambar denah, tampak, potongan, gambar rencana, gambar detail dan rencana anggaran biaya.

Referensi alur desain tersebut juga digunakan pada penelitian sebelumnya yaitu pada penelitian Setyabudi, et al. (2017) dan Hasibuan, et al. (2020).

\section{HASIL DAN PEMBAHASAN}

\section{Inventarisasi}

\section{Kondisi Umum Tapak}

Secara administratif, Taman Trunojoyo berada di Kecamatan Klojen yaitu di kawasan pusat pemerintahan Kota Malang. Status kepemilikan/penanggung jawab adalah Dinas Kebersihan dan Pertamanan Kota Malang. Luas keseluruhan tapak yaitu sebesar $5.840 \mathrm{~m}^{2}$, dan memiliki aksesibilitas yang tinggi sehingga memudahkan pengunjung untuk mengunjungi lokasi tersebut. Jalan menuju tapak dapat di akses melalui Jalan Kertanegara, Jalan Trunojoyo dan Jalan Pajajaran (Gambar 2). Secara geografis taman tersebut terletak pada koordinat 11226.14 hingga 11240.42 BT dan 07736.38 hingga 008 01.57 LS. dengan batas wilayah sebagai berikut:

a) Jalan Kartanegara di sebelah Utara

b) Jalan Trunojoyo dan Stasiun Kota Baru di sebelah Selatan

c) Jalan Sultan Agung dan kios-kios di sebelah Barat

d) Jalan Pajajaran di sebelah Timur

Sirkulasi pada tapak ini dibagi menjadi tiga jalur. Jalur sirkulasi di dalam tapak dapat dilalui oleh pejalan kaki yang berada di sebelah Selatan dan Utara, sementara di sebelah Timur dan Barat tapak dapat diakses dengan sepeda motor, mobil pribadi, bus, angkot dan taksi. Jalur sirkulasi di luar tapak juga dapat dilalui oleh pejalan kaki dengan tersedia jalur pejalan kaki (pedestrian) yang mengelilingi tapak.

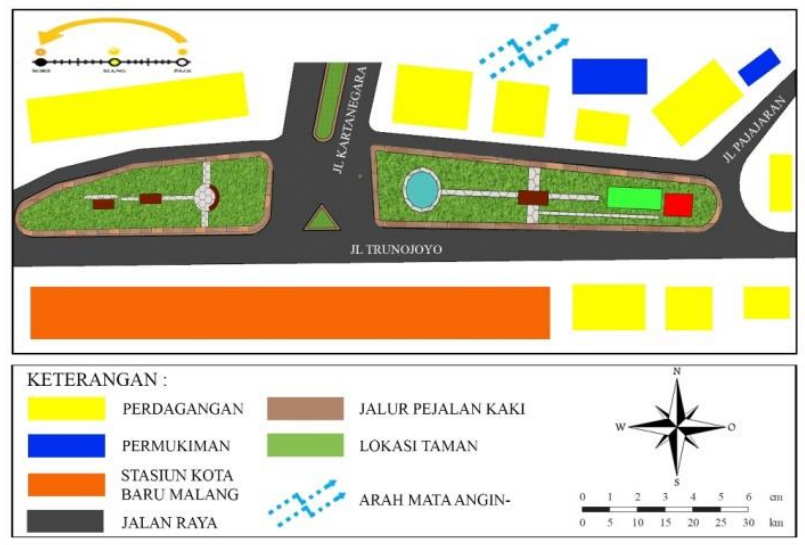

Gambar 2. Peta Iventarisasi

Secara geologis tapak merupakan dataran datar atau landai. Jenis tanah pada tapak adalah asosiasi andosol coklat dan abu-abu humus yang mengandung unsur hara 
yang sedang hingga tinggi sehingga cukup baik untuk tanaman. Menurut data dari Kabupaten Malang dalam angka tahun 2018, hasil pantauan tiga pos pemantauan stasiun Klimatologi Karangploso Malang, suhu udara rata-rata relatif rendah, berkisar antara $22,7-25,1^{\circ} \mathrm{C}$. Sedangkan suhu maksimum mencapai $32,7^{\circ} \mathrm{C}$ dan suhu minimum $18,4^{\circ} \mathrm{C}$. Rata-rata kelembaban udara berkisar 79 - 86\%. dengan kelembaban maksimum 99\% dan minimum mencapai $40 \%$. Seperti umumnya daerah lain di Indonesia, Kota Malang mengikuti perubahan putaran 2 musim, yakni musim hujan dan musim kemarau. Pada tapak juga terdapat berbagai macam jenis-jenis fasilitas taman dan jenis-jenis vegetasi taman. Tidak terdapat satwa yang menjadi ciri khas pada taman, satwa yang terdapat di dalam taman merupakan satwa liar seperti: burung pipit, kupu-kupu, kadal dan lainnya.

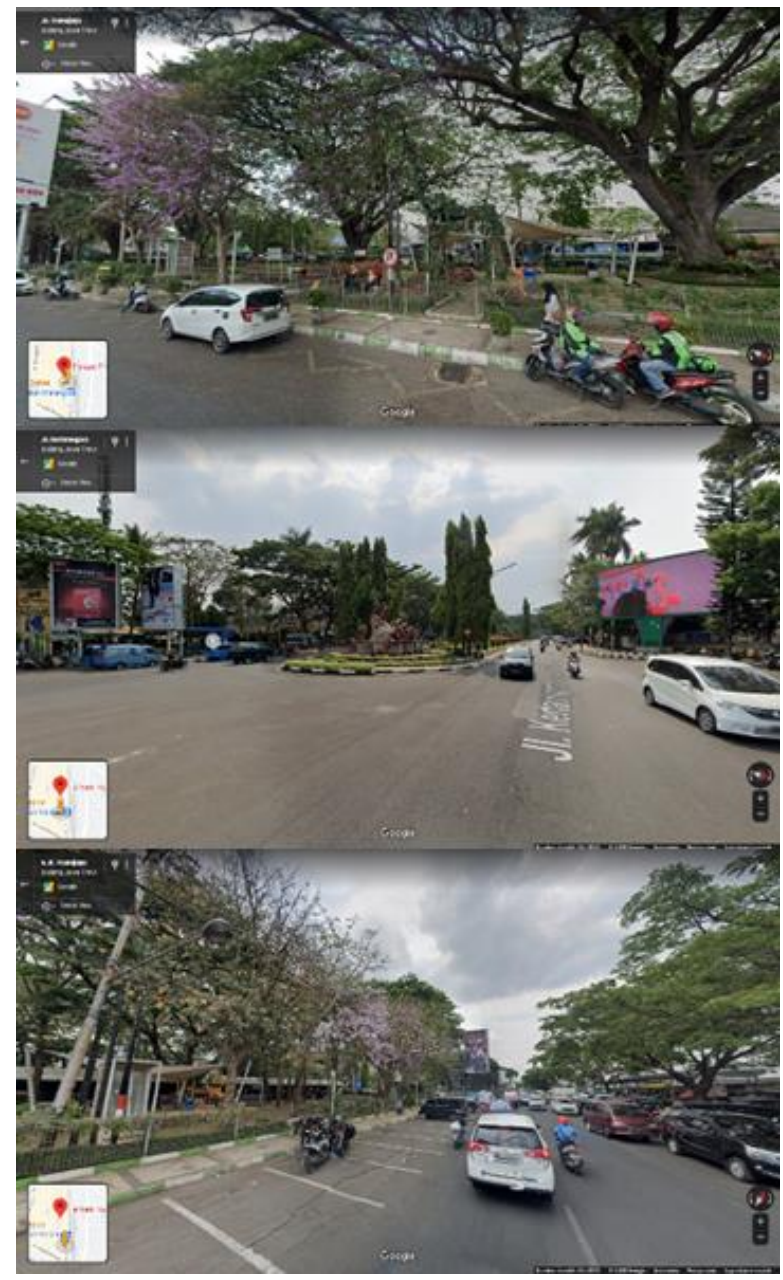

Gambar 3. (atas) Taman Sisi Kanan, (tengah) Median Sebagai Pemisah Taman, (bawah) Taman Sisi Kiri Sumber: Google Maps (2020)

\section{Aspek Sosial}

Kondisi eksisting pada aspek sosial terjadi beberapa penyimpangan aktivitas atas ruang yang dirancang. Pengunjung tapak cukup beragam pada setiap harinya, mayoritas adalah masyarakat sekitar dan dari luar daerah. Berdasarkan hasil survei di lapangan pada pagi hari user/pengguna taman cenderung sepi pada hari kerja, aktivitas yang terlihat hanya petugas kebersihan taman. Pada siang hari pengunjung yang masuk kedalam taman mayoritas yaitu para pelajar SMP dan SMA. Keberadaan pedagang kaki lima yang berjualan di luar dan menempel pagar taman membuat pagar menjadi rusak dan patah disebabkan oleh pembeli yang cenderung membeli makanan lewat celah pagar yang rusak. Pada sore hari aktifitas di dalam taman cenderug anak remaja yang hanya duduk dan berkumpul serta para pedagang yang beristirahat dan tidur di bangku taman atau amphiteatre.

\section{Aspek Pengelola}

Taman Kota Trunojoyo Kota Malang dikelola langsung oleh bidang Kebersihan dan Pertamanan yang berada di bawah naungan Badan Lingkungan Hidup (BLH) Kota Malang. Berdasarkan hasil wawancara dengan Kasi Pengembangan Kabit Pertamanan, bentuk pengelolaan yang dilakukan setiap hari secara rutin oleh petugas UPT (Unit Pelaksana Teknis) BLH Kota Malang. Pembersihan sampah dilakukan secara rutin dua kali setiap hari atau sebanyak 60 kali dalam satu bulan. Waktu pengerjaan pembersihan dilakukan pada pagi hari mulai pukul 08.00 hingga istirahat pukul 12.00 siang hari kemudian petugas mulai kembali bekerja dimulai pukul 13.00. Pemeliharaan elemen vegetasi dan fasilitas tapak dikelola oleh bidang Pertamanan BLH Kota Malang. Berdasarkan hasil wawancara yang telah dilakukan dengan salah satu Kasi Pengembangan Kabit Pertamanan Kota Malang, Ir. Endah Setiyowati. Beliau menuturkan beberapa hal terkait struktur teknis pemeliharaan taman. Jadwal penyiraman dan pemangkasan dilakukan oleh petugas UPT bidang Pertamanan BLH secara teratur pada musim kemarau kemudian pengecekan kondisi fisik dan perbaikan unit fasilitas taman dilakukan secara berkala. Pada musim penghujan, jadwal penyiraman dan pemangkasan dilakukan secara kondisional.

\section{Kajian Pendahuluan sebagai Dasar Perancangan}

Pada bagian pendahuluan diketahui beragam permasalahan, diantaranya: 1) secara visual belum menunjukkan gaya yang kontekstual sehingga belum mewakili identitas Kota Malang, 2) terjadi penyimpangan perilaku/aktivitas, 3) pemilihan hardscape dan softscape yang kurang sesuai sehingga kurang estetis, 4) persebaran pengunjung kurang merata oleh karena penataan zonasi ruang yang kurang sesuai. Permasalahan tersebut sebagai dasar peneliti untuk melaksanakan rancangan ulang. Suatu rancangan mengalami siklus proses yang mana ditemui masalah, mencari gagasan untuk penyelesaian, penerapan gagasan, dan evaluasi sehingga dihasilkan rancangan yang lebih sempurna.

\section{Programing}

\section{Analisis Kebutuhan Ruang, Aktivitas dan Besaran Ruang}

Analisis ini digunakan untuk mengetahui kebutuhan ruang yang akan diwadahi dalam Taman Kota Trunojoyo Kota Malang beserta dengan ukuran yang kemudian disesuaikan dengan luasan yang ada pada tapak tersebut.

\section{Analisis Kebutuhan Ruang dan Aktivitas}

Jadi untuk kebutuhan ruang dan aktivitas berdasarkan fungsi yang terdapat di Taman Kota Trunojoyo Kota Malang adalah sebagai berikut: 
Tabel 1. Kebutuhan Ruang dan Aktivitas

\begin{tabular}{|c|c|c|c|}
\hline Kebutuhan Ruang & Aktivitas & Pelaku & Ukuran \\
\hline Ruang Informasi & & & $2,00 \mathrm{~m}^{2} /$ org $(\mathrm{MHB})$ \\
\hline Monumen Singa & & & $1,50 \mathrm{~m}^{2} /$ org (Asumsi) \\
\hline Gazebo & $\begin{array}{l}\text { Bersantai dan Sport } \\
\text { berfoto }\end{array}$ & pengunjung & $\begin{array}{l}2,00 \mathrm{~m}^{2} / \text { org } \\
\text { (NAD) }\end{array}$ \\
\hline Parkiran & $\begin{array}{l}\text { Parkiran kendaraan } \\
\text { motor dan mobil }\end{array}$ & $\begin{array}{l}\text { Penjaga } \\
\text { pengunjung }\end{array}$ & $\begin{array}{l}3 \mathrm{~m}^{2} / \mathrm{mtr} \\
10 \mathrm{~m}^{2} / \mathrm{mbl} \\
\text { (NAD) }\end{array}$ \\
\hline Plaza & atraksi & Pengunjung & $2,00 \mathrm{~m}^{2} /$ org $(\mathrm{MHB})$ \\
\hline Ruang Tunggu & & Pengunjung & $2,00 \mathrm{~m}^{2} /$ org $(\mathrm{MHB})$ \\
\hline Area Bermain Anak & area bermain anak & Pengunjung & $2,00 \mathrm{~m}^{2} /$ oang $(\mathrm{MHB})$ \\
\hline Kursi Taman & bersantai & Pengunjung & $2,00 \mathrm{~m}^{2} /$ org (NAD) \\
\hline Area Terapi & terapi & pengunjung & $2,00 \mathrm{~m}^{2} /$ org $(\mathrm{MHB})$ \\
\hline
\end{tabular}

Keterangan:

NAD (Neufert dan Neufert, 2012)

MHB (Buxton, 2015)

\section{Batasan dan Analisis Tapak}

\section{Batasan Tapak}

Sebelah Utara berbatasan dengan Jalan Kartanegara, Sedangkan sebelah Selatan berbatasan dengan Stasiun Kota Baru, kemudian sebelah Timur berbatasan dengan Jalan Pajajaran dan sebelah Barat berbatasan dengan kioskios dan Jalan Sultan Agung Kota Malang.

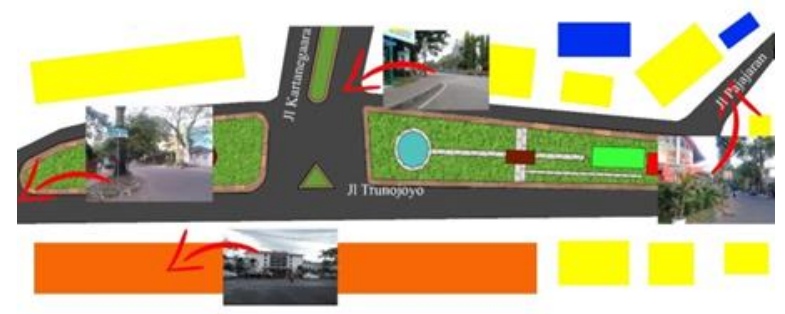

Gambar 4. Batasan Tapak

\section{Analisis Tapak}

View yang bagus terdapat pada arah Selatan dan Barat yaitu area stasiun, pada arah Timur terdapat pemandangan yang ada di dalam tapak, sedangkan view yang buruk pada arah utara yaitu terdapat tempat banyak sekali area parkir liar. Pusat keramaian dari arah Utara yaitu dari Jalan Trunojoyo dan Stasiun Kota Baru, Jalan

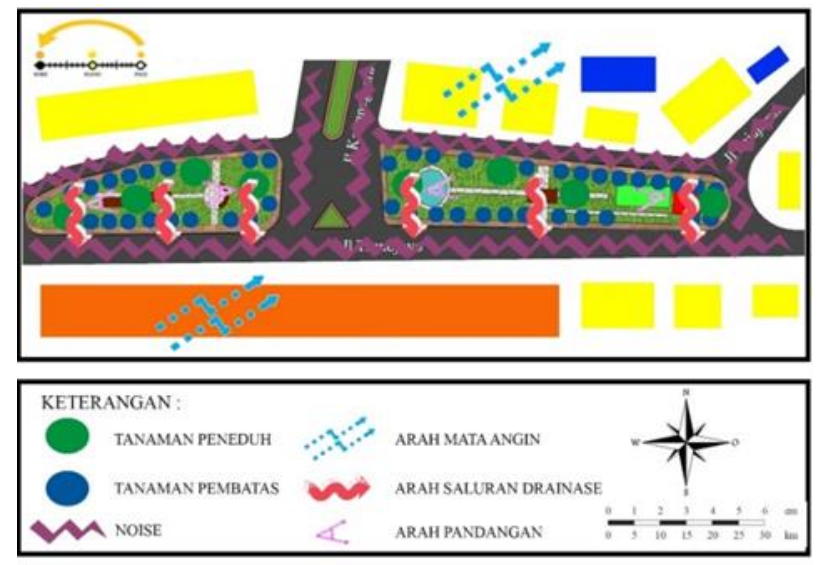

Gambar 5. Analisis Seluruh Tapak
Pajajaran dan Jalan Kertanegara, langkah antisipasi dengan vegetasi pembatas dan bangunan lebih area tengah tapak. Vegetasi yang sudah ada dapat untuk peneduh dan pengarah. Pohon untuk pembatas dan tanaman hias, perlu ditambahkan. Drainase dari tapak akan dialirkan ke saluran drainase yang di bawah trotoar. Orientasi bangunan ke arah Timur-Barat agar tidak panas dan arah pandangan bangunan menghadap ke arah taman.

\section{Konsep}

\section{Gagasan Umum}

Pemilihan bentuk dasar akan ditransformasikan menjadi massing block dari taman dan bangunannya. Bentukan ini dirasa optimal dengan analogi dari struktur daun. Peneliti terinspirasi dari kondisi alam sehingga muncul gagasan tersebut. Jika diperhatikan pada selembar daun terdapat tangkai, pelepah, dan tulang daun. Masing-masing sinergis membentuk suatu sistem. Analogi tersebut dapat digeneralisasikan menjadi bentukan dasar berupa garis dan bidang dapat diterapkan pada taman. (Gambar 6).

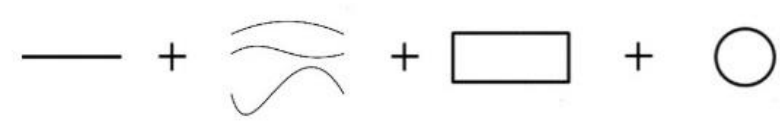

Gambar 6. Bentuk Dasar Bangunan

\section{Eksplorasi Bentuk Gabungan Masa}

Konsep utama yang digunakan dalam perancangan kawasan Taman Kota Trunojoyo Kota Malang adalah tanaman Andong Merah (Cordyline fruticosa), dimana pada area tapak akan menerapkan unsur-unsur modern taman dengan bentukan desain dari pola sirkulasi sel daun Andong Merah. Berdasarkan SK Gubernur Nomor 5225/16774/032/1996 ditetapkan bahwa pohon andong merah merupakan ciri khas flora Kota Malang. Pengambilan andong merah sebagai inspirasi desain akan diterapkan pada unsur hardscape-nya pada sirkulasi dan fasilitas aktivitasnya. Selain andong merah, Pemerintah Kota Malang juga menganjurkan untuk menambah tanaman khas yaitu puring dan kol banda. Tiga tanaman tersebut rupanya memiliki banyak khasiat. 


\section{a) Andong Merah (Cordyline fruticosa)}

Pohon andong merah (Cordyline fruticosa) memiliki dominasi warna merah daripada warna hijau, sehingga memiliki kesan "berani, tegas, dan formal” (Gambar 7).

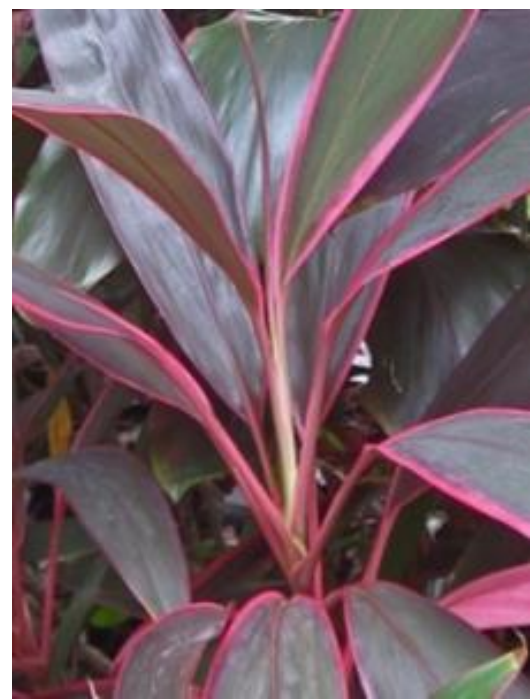

Gambar 7. Filosofi Andong Merah

\section{b) Sel Daun}

Analogi lainnya berasal dari bentuk pola sirkulasi sel daun. Di dalam sel daun terdapat organel kloroplas yang berperan penting dalam proses fotosintesis untuk mengubah energi cahaya menjadi energi kimia. Proses fotosintesis berkaitan erat dengan pertumbuhan dan perkembangan hidup tanaman. Serupa dengan hal tersebut, sel-sel di dalam tubuh manusia juga terus tumbuh dan berkembang. Dengan pertumbuhan dan perkembangan sel, diharapkan di dalam tubuh manusia yang sehat terdapat jiwa yang kuat agar tetap tumbuh dan berkembang (Gambar 8).

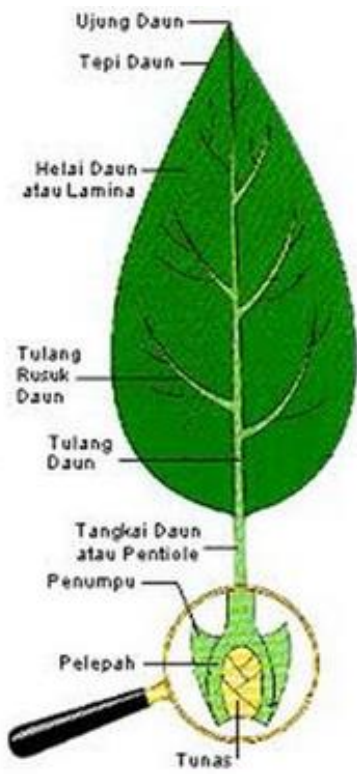

Gambar 8. Konsep Filosofi Sel Daun Sumber: Asmawati (2014)

Adapun menurut analisis, ada elemen yang patut dipertahankan dan dirubah.
Tabel 2. Analisis hardscape dan softscape

\begin{tabular}{lll}
\hline Elemen & Bagian & $\begin{array}{l}\text { Perlu/Tidak } \\
\text { Perubahan }\end{array}$ \\
\hline Hardscape & $\begin{array}{l}\text { Kanopi dengan struktur } \\
\text { tenda }\end{array}$ & Perlu \\
\hline & Pagar luar & Perlu \\
\hline & Jalur pedestrian dalam & Perlu \\
\hline & Jalur pedestrian luar & Tidak \\
\hline Area tempat duduk & Perlu \\
\hline Signage/papan nama & Perlu \\
\hline $\begin{array}{l}\text { Bangunan pengelola, } \\
\text { perpustakaan, pujasera }\end{array}$ & Tidak \\
\hline & Playground dan plaza & Perlu \\
\hline Air mancur & Perlu \\
\hline Gerbang masuk & Perlu \\
\hline $\begin{array}{l}\text { Pohon flamboyan } \\
\text { sebagai peneduh }\end{array}$ & Tidak \\
\hline Grass area & Perlu \\
\hline $\begin{array}{l}\text { Tanaman estetika } \\
\text { ditambahkan }\end{array}$ & Perlu \\
\hline
\end{tabular}

Konsep lain yang perlu ditambahkan adalah dengan pendekatan lanskap kota, wujudnya secara konkrit sebagai berikut.

1) Ruang untuk masyarakat. Hal tersebut dicapai dengan menyediakan ruang publik pada masyarakat, akan merasa memiliki (sense of belonging). Ruang tersebut dicapai dengan optimalisasi pembagian tata ruang taman

2) Kontekstual. Pembangunan baru harus memperkaya kualitas tempat-tempat yang ada.

3) Membuat koneksi. Sebuah rung harus mudah diakses dan terintegasi secara fisik dan visual dengan lingkungan.

4) Bekerja dengan alam. Ruang yang dapat menyajikan keseimbangan lingkungan antara alam dan buatan manusia dengan penggunaan sumber daya alam seperti; iklim, landform dan ekologi.

5) Menggabungkan kegunaan sesuai dengan bentukan. Tempat yang nyaman dan menyenangkan dan mempertemukan berbagai macam kebutuhan user dalam sekala besar.

6) Manajemen investasi. Agar sebuah proyek dapat dikembangkan dan diterima mereka harus secara ekonomi dapat dibangun, dikelola dan dipertahankan.

7) Desain untuk perubahan. Perkembangan baru harus cukup fleksibel untuk merespon tantangan di masa depan, gaya hidup dan demografi.

\section{Site Plan}

Berdasarkan hasil desain Taman Kota Trunojoyo Kota Malang, memberikan rencana detail dengan semua unsur didalamnya. Rencana Site Plan Taman Trunojoyo Kota Malang terdapat ruang-ruang publik yang dapat meningkatkan efisiensi perekonomian masyarakat. Adapun kriteria desain Taman Trunojoyo yang baru adalah sebagai berikut.

1) Area penerima, berupa main gate dengan aksentuasi sehingga lebih mudah terlihat.

2) Ornamentasi yang kontekstual, ditempuh dengan menghadirkan ornamentasi sejarah namun tidak kuno. Hal ini mengacu pada rancangan pusat kota 
yang pernah dikembangkan sebagai kota kolonial Belanda

3) Sirkulasi, berupa jalur yang bisa menghubungkan antara taman sisi kanan dan kiri sehingga terintegrasi. Wujudnya bisa berupa jembatan penyeberangan.

4) Area pembatas, selama ini batas dirancang dengan pagar besi, namun kesannya kaku karena pengunjung secara ruang dibatasi secara tegas. Alternatifnya adalah rancangan pagar dengan kombinasi antara hardscape seperti pagar bata semi tertutup dan softscape yaitu penitian
5) Area pedestrian selama ini memiliki desain kaku dengan bentukan bersudut, sehingga perlu yang lebih luwes dengan pola organik

6) Area tempat duduk, dirancang dengan area teduhan yaitu gazebo. Selama ini tempat duduk jumlahnya kurang banyak dan terbuka sehingga pada saat hujan pengunjung terkena tampias. Pada struktur tenda terlihat sangat kontras sehingga perlu diganti.

7) Fasilitas street furniture seperti tempat sampah, titik lampu juga disesuaikan dengan ornamentasi tertentu.
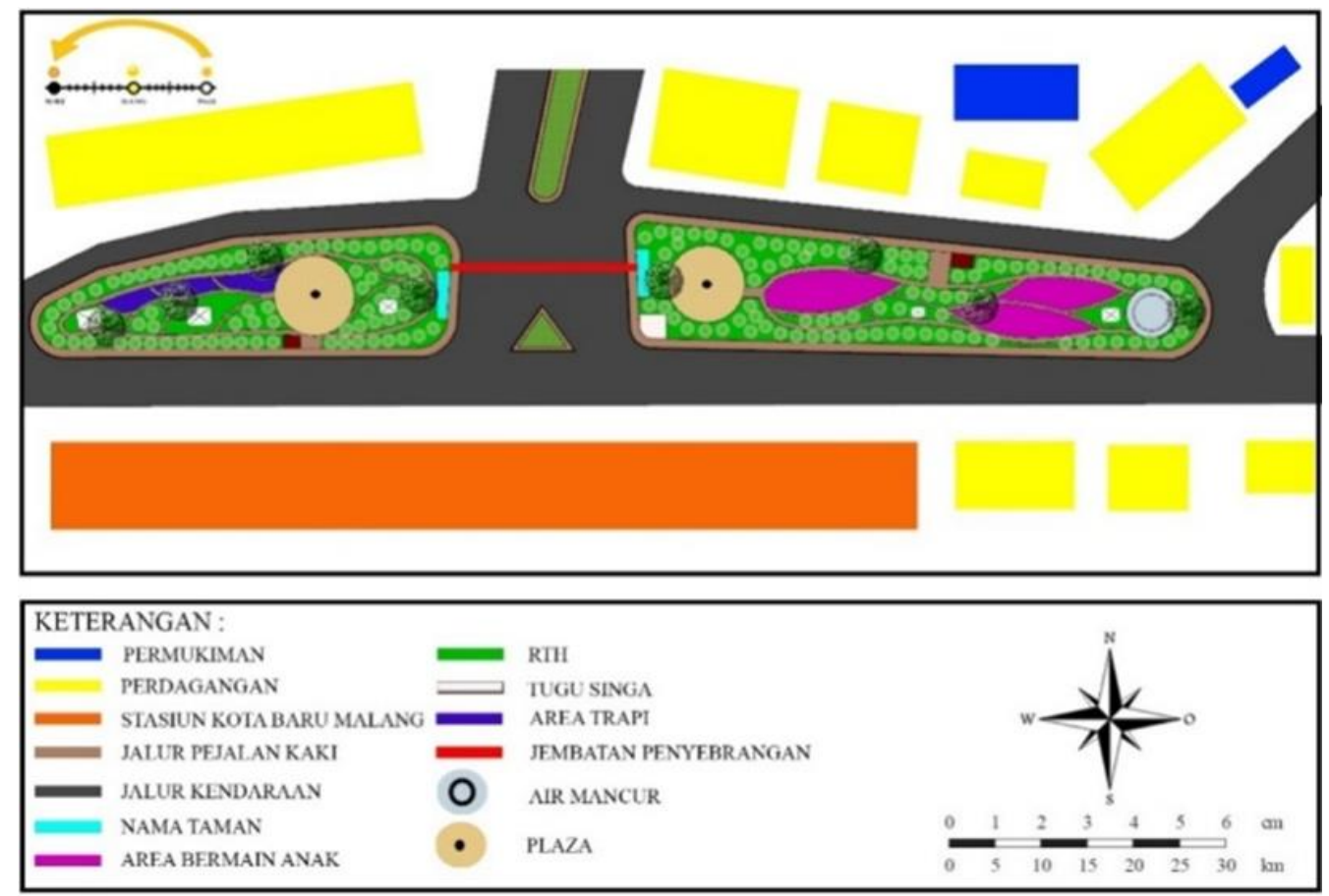

Gambar 9. Site Plan

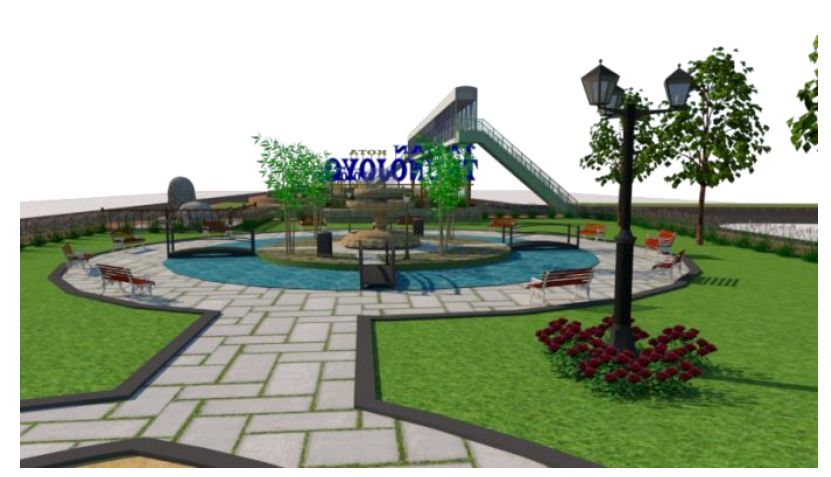

Gambar 10. Plaza

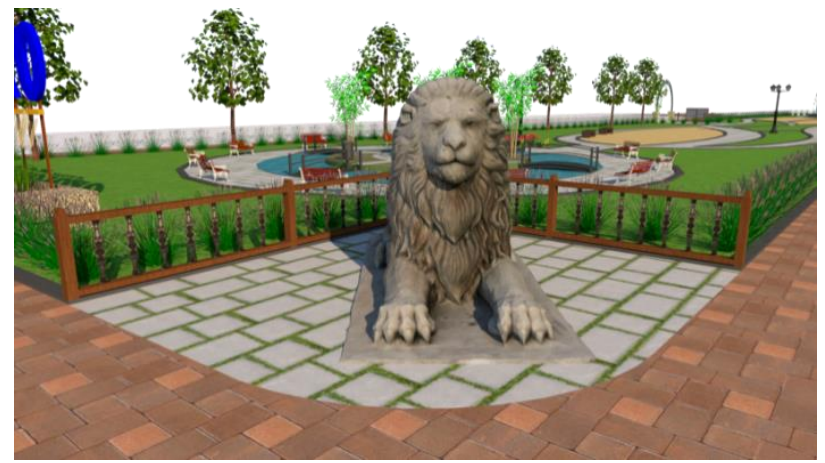

Gambar 12. Patung Singa

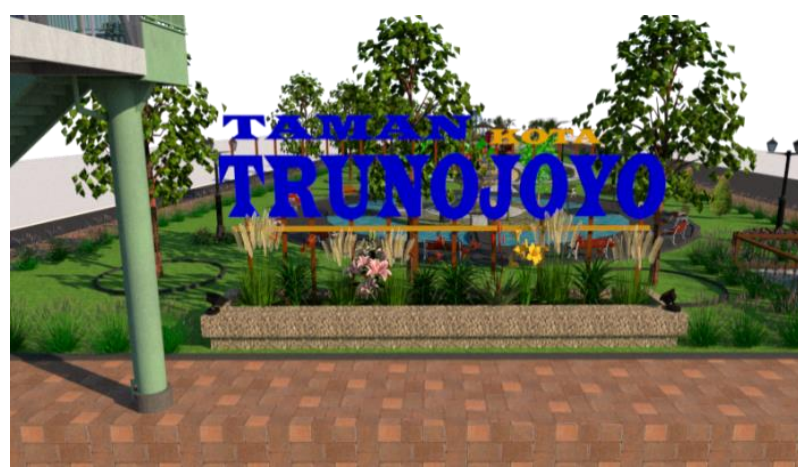

Gambar 11. Nama Taman

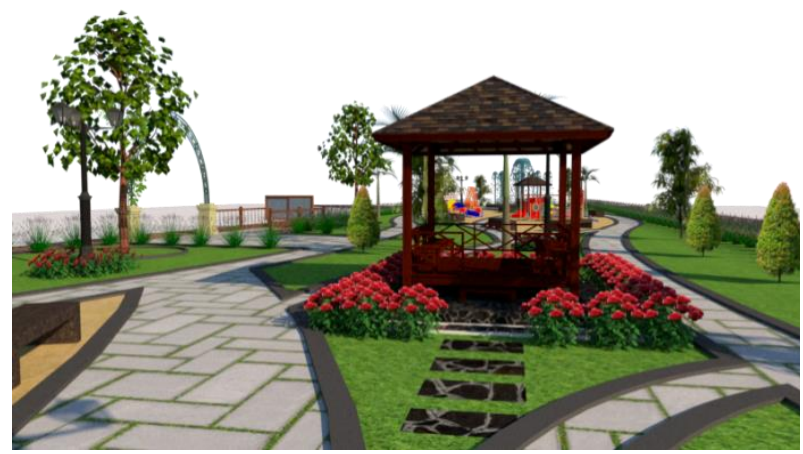

Gambar 13. Gazebo 


\section{Potongan}

Redesain Taman Kota Trunojoyo Kota Malang memiliki tampak potongan yang terbagi menjadi dua segmen yaitu, tampak potongan $\mathrm{A}-\mathrm{A}^{\prime}$ yang memotong bagian tapak secara vertikal dan tampak potongan B-B' yang memotong bagian tapak secara horizontal. Ilustrasi tampak potongan tapak dapat dilihat pada Gambar berikut.

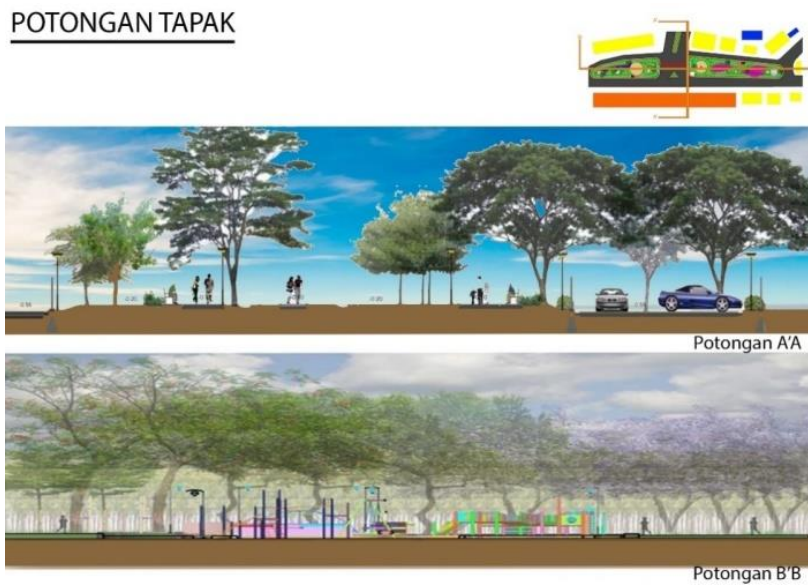

Gambar 14. Potongan

\section{Rencana-Rencana Penanaman}

Kriteria tanaman pada taman kota menurut peraturan menteri no. 05/prt/m/2008 adalah tanaman yang aman, tidak beracun, tidak berduri, tajuk cukup rindang, ketinggian bervariasi namun seimbang, kecepatan tumbuh sedang, tanaman lokal, jarak tanam setengah rapat, tahan penyakit, dan mengundang burung. Adapun tanaman yang dipilih sebagai berikut.

Tabel 3. Rencana-rencana Penanaman

\begin{tabular}{clll}
\hline No & Nama Ilmiah & Nama Lokal & Kegunaan \\
\hline 1 & $\begin{array}{l}\text { Cordyline } \\
\text { fruticose }\end{array}$ & $\begin{array}{l}\text { Andong } \\
\text { merah }\end{array}$ & Estetika \\
\hline 2 & Begoniaceae & Begonia & Estetika \\
\hline 3 & $\begin{array}{l}\text { Alcantarea } \\
\text { imperialis }\end{array}$ & $\begin{array}{l}\text { Bromelia } \\
\text { giant }\end{array}$ & Estetika \\
\hline 4 & $\begin{array}{l}\text { Passiflora foetida } \\
\text { Carambusa } \\
\text { mini }\end{array}$ & Estetika \\
\hline 5 & $\begin{array}{l}\text { Phaseolus } \\
\text { vulgaris }\end{array}$ & Erva merah & Estetika \\
\hline 6 & $\begin{array}{l}\text { Codiaeum } \\
\text { variegate }\end{array}$ & Puring kura & Estetika \\
\hline 7 & $\begin{array}{l}\text { Excoecaria } \\
\text { cochinchinesis }\end{array}$ & $\begin{array}{l}\text { Sabang } \\
\text { Darah }\end{array}$ & Estetika \\
\hline 8 & $\begin{array}{l}\text { Melastoma } \\
\text { candidum }\end{array}$ & $\begin{array}{l}\text { Sanggani } \\
\text { mini }\end{array}$ & Estetika \\
\hline 9 & $\begin{array}{l}\text { Cuphea } \\
\text { hyssopifolia }\end{array}$ & $\begin{array}{l}\text { Taiwan } \\
\text { beauti unggu }\end{array}$ & Estetika \\
\hline 10 & Syzygium oleana & Pucuk Merah & $\begin{array}{l}\text { Pembatas } \\
\text { dan Estetika }\end{array}$ \\
\hline 11 & $\begin{array}{l}\text { Acalypha } \\
\text { siamensis }\end{array}$ & The-tehan & $\begin{array}{l}\text { Pembatas } \\
\text { dan Estetika }\end{array}$ \\
\hline 12 & Chlorophytum sp & Liliparis & Estetika \\
\hline 13 & $\begin{array}{l}\text { Pennisetum } \\
\text { purpureum }\end{array}$ & $\begin{array}{l}\text { Rumput } \\
\text { Gajah }\end{array}$ & $\begin{array}{l}\text { Penutup } \\
\text { Tanah }\end{array}$ \\
\hline 14 & $\begin{array}{l}\text { Ficus benjamina } \\
\text { Pohon } \\
\text { Beringin }\end{array}$ & peneduh \\
\hline & & & \\
\hline
\end{tabular}

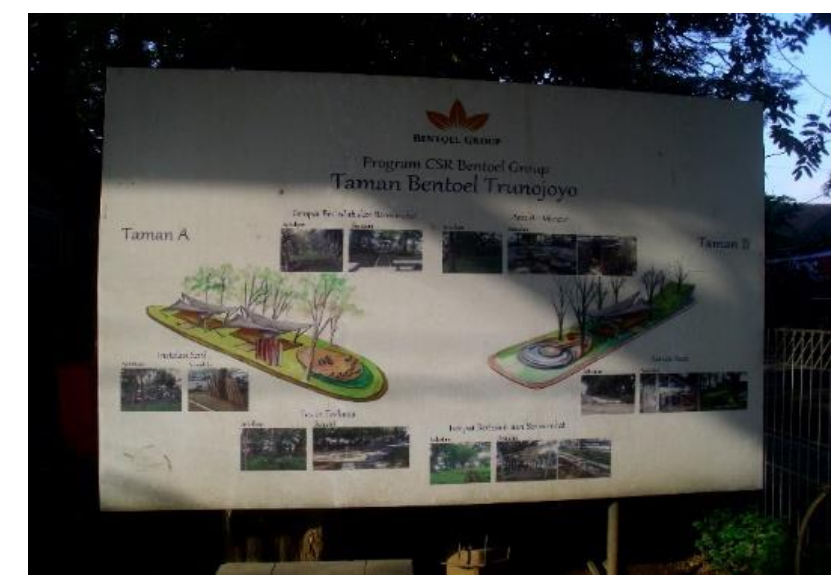

Gambar 17. Desain Lama

Nilai kebaruan pada penelitian ini adalah dari aspek lokasi rancangan berada pada kota dengan nilai peninggalan sejarah, sehingga dalam rancangan taman baru memenuhi kaidah kontekstual, selain itu juga berada pada pusat kota dan sebagai gerbang masuk dari berbagai kota lain dari jalur kereta, sehingga dapat memberikan kesan masuk 
Kota Malang bagi pengunjung. Aspek lainnya adalah dalam penarikan konsep, yaitu analogi dari bentuk dan sifat daun. Daun memiliki bagian-bagian tertentu yang membentuk suatu sistem, seperti jalur sirkulasi fotosintesis. Penerapan tersebut juga berlaku pada taman rancangan, dengan merubah jalur sirkulasi dengan bentukan yang kaku dengan bentukan yang lebih luwes dari bentuk daun.

Tabel 4. Perbandingan Desain Awal dan Desain Baru

\begin{tabular}{lll}
\hline No & Desain awal & Desain baru \\
\hline 1 & Kurang efesien & Sudah efesien \\
\hline 2 & $\begin{array}{l}\text { Tata letak utilitas } \\
\text { dan fasilitas } \\
\text { kurang teratur }\end{array}$ & $\begin{array}{l}\text { Tata letak utilitas dan } \\
\text { fasilitas sudah teratur }\end{array}$ \\
\hline 3 & Pemanfaatan & Pemanfaatan ruang \\
& ruang pada desain \\
& taman kurang baik & \\
\hline
\end{tabular}

Hasil penelitian ini berupa konsep rancangan ulang taman Trunojoyo dengan pendekatan lanskap kota melengkapi konsep education-interactive yang ditawarkan oleh pemerintah. Adapun generalisasi konsepnya sebagai berikut:

1) Main entrance, atau jalur masuk utama harus terlihat dari pengunjung dari sisi arah stasiun atau arah lainnya

2) Bangunan di atas taman seperti perpustakaan, pujasera, dan sebagainya harus memiliki ornamentasi yang kontekstual sehingga memperkuat citra kota

3) Area pedestrian dalam taman terinspirasi dari bentukan analogi lengkung daun sehingga tidak terkesan kaku, sedangkan area pedestrian luar kodisinya tetap

4) Penambahan elemen air pada node berupa air mancur sehingga kesan taman tidak kering.

5) Area pembatas antara ruang luar dan luar berupa pagar diganti dengan kombinasi antara hardscape dan softscape sehingga kesannya tidak kaku

6) Seluruh area taman diteduhkan dengan pohon flamboyan yang kondisinya tidak akan berubah, sedangkan tanaman perdu memberikan warna khas yaitu berbunga warna ungu. Keseragaman ini juga dapat memberikan kesan bagi pengamat.

7) Tanaman Andong Merah sebagai tanaman lokal Malang ditambahkan pada setiap sudut taman

\section{SIMPULAN}

Penelitian ini merupakan upaya atau konsep penyempurnaan taman yang sudah ada sebelumnya sehingga disebut juga dengan redesain atau perancangan ulang. Suatu hasil rancangan tidak akan berhenti di tempat tetapi berputar dalam suatu siklus yaitu identifikasi permasalahan, konsep, hasil rancangan, implementasi dan evaluasi. Setelah tahap evaluasi ditemukan permasalahan sebagai bahan rancangan kembali. Begitupula di Taman Trunojoyo. Taman ini terletak pada pusat kota dan pusat pemerintahan Kota Malang yang notabene adalah kota yang dikembangkan pada masa kolonial sehingga nuansa atau karakter kolonial cukup kuat selain itu, Thomas Karsten mengembangkan kota dengan konsep Garden City sehingga diketahui banyak jalur hijau di perkotaan.
Berbeda kondisi pada taman Trunojoyo yang sebelumnya dirancang oleh pemerintah, kontras dengan kondisi Kota Malang. Banyak unsur dianggap kurang kontekstual sehingga dalam penelitian ini, taman dirancang dengan pendekatan lanskap kota. Inti dari konsep tersebut adalah mengangkat kembali nuansa Kota Malang, mengganti beberapa unsur hardscape dan softscape dan merancang kembali organisasi ruang yang dirasa kurang yaitu ruang bermain anak, ruang komunikasi, ruang inti dan ruang rekreasi. Adapun bentukan yang menjadi inspirasi adalah bentukan daun, yang memiliki sifat tidak kaku.

\section{DAFTAR PUSTAKA}

Amin, A.M., 2012, Sustainable Urban Landscape: An Approach For Assessing And Appropriating Indicators. Archnet-IJAR, Vol. 6, No. 2, hal. 98-114.

Asmawati. 2014. Bagian Tumbuhan dan Fungsinya. (Online). diakses oktober 2020. https://asmawatyfricilia. wordpress.com/2014/10/19/bagian-tumbuhandan-fungsinya/

Budiyono, D., Nurlaelih, E.E., Djoko, R. 2012. Lanskap Kota Malang Sebagai Obyek Wisata Sejarah Kolonial. Jurnal Lanskap Indonesia, 4(1).

Buxton, P. (Ed.). 2015. Metric handbook: planning and design data. Routledge.

Creswell, J.W., Poth, C.N. 2016. Qualitative inquiry and research design: Choosing among five approaches. Sage publications.

DJPRDP. 2008. Peraturan Menteri Pekerjaan Umum Nomor 05 tentang pedoman penyediaan dan pemanfaatan ruang terbuka hijau di kawasan perkotaan. Direktorat Jenderal Penataan Ruang Departemen Pekerjaan Umum.

Gold, S.M. 1980. Recreation Planning and Design. McGrawHill Company. New York

Gunawan, I. 2013. Metode penelitian kualitatif. Jakarta: Bumi Aksara, 143.

Hasibuan, M.S. ., Syahadat, R.M., Sidabutar, L. 2020. Perencanaan dan Perancangan Lanskap Taman Maju Bersama Haji Saibun di Kelurahan Jati Padang, Jakarta Selatan. Jurnal Infrastruktur, 6(1), 15-24.

Hakim, R., Utomo, H. 2012. Komponen Perancangan Arsitektur Lansekap. Jakarta: PT. Bumi Aksara.

Helmi. 2008. Mendesain Logo milik Surianto Rustan.

Malang, B.P.S.K. 2018. Kabupaten Malang dalam Angka 2018. BPS Kabupaten Malang

Neufert, E., Neufert, P. 2012. Architects' data. John Wiley \& Sons.

Permana, I.A., Fatimah, I.S. 2017. Redesign Taman Kota Kabupaten Bogor Dengan Pendekatan Urban Landscape Design. Jurnal Arsitektur Lansekap, 3 (1): 39, 48. 
Putri, A.Y., Ernawati, J., Ramdlani, S. 2017. Pola Aktivitas pada Ruang Publik Taman Trunojoyo Malang. Jurnal Mahasiswa Jurusan Arsitektur, 5(4).

Santoso, I., Safrilia, A., Tutuko, P. 2018. Konservasi Bangunan Stasiun Kota Baru Malang. Temu Ilmiah Ikatan Peneliti Lingkungan Binaan Indonesia (IPLBI) 7, 51-57.

Setyabudi, I. 2016. Elemen dan Proses Desain Arsitektur Lanskap Taman Rumah Tinggal. Malang: Dream Litera.

Setyabudi, I., Nuraini, N., Alfian, R., Nailufar, B. 2017. Konsep Taman Edukasi pada Sekolah Dasar di Kota Malang (Studi Kasus: SDN Lowokwaru 3 Malang). RUAS (Review of Urbanism and Architectural Studies), 15(1), 23-34.

Syafiq, M. 2017. Perancangan Taman Vertikal Pada Lingkungan Koridor Padat Kota Dengan Pendekatan Konsep Sustainable Urban Landscape (Studi Kasus: Koridor Jalan Basuki Rahmat). (Doctoral dissertation, Institut Teknologi Sepuluh Nopember).

Utomo, H.P. 2015. Re-Desain Alun-Alun Bojonegoro Sebagai Ruang Terbuka Publik Dengan Pendekatan Sustainable Urban Landscape (Doctoral dissertation, Institut Teknologi Sepuluh Nopember).

Yuliani, W. 2018. Metode Penelitian Deskriptif Kualitatif Dalam Perspektif Bimbingan Dan Konseling. QUANTA, 2(2), 83-91. 